\title{
Kemampuan Menulis Cerpen melalui Penerapan Media Gambar Berseri Siswa Kelas VIII SMP Negeri 7 Palopo
}

\author{
Suparman \& Theresia Durang \\ Universitas Cokroaminoto Palopo \\ suparman@uncp.ac.id
}

\begin{abstract}
Abstrak
Penelitian ini bertujuan untuk mendeskripsikan hasil penerapan media gambar beseri tarhadap pembelajaran menulis cerpen, mendeskripsikan hasil perbedaan secara signifikan hasil belajar menulis cerpen antara yang menggunakan media gambar berseri dan tanpa menggunakan media gambar berseri. Jenis penelitian yang digunakan dalam penelitian ini adalah one group peretest posttets design. Pengambilan sampel dalam penelitian ini dilakukan dengan menentukan langsung dengan pertimbangan bahwa semua kelas memiliki kesempatan yang sama dan homogen. Hasil uji perbandingan rata rata nilai pretets kelas VIII SMP Negeri 7 Palopo adalah 65,6 sedangkan posttest kelas VIII SMP Negeri 7 Palopo adalah 78,4. Hasil penelitian ini dapat dilihat dari nilai rata rata siswa sebelum menerapkan media gambar berseri adalah 66,6 yang diperoleh dari hasil bagi jumlah seluru nilai $\left(\sum \mathrm{X}\right)$ dengan jumlah sampel $(\mathrm{N})$ atau $\left.\left(\sum \mathrm{X} / \mathrm{N}\right)=1,620 / 25=64,8\right)$ sedangkan nilai rata rata setelah menerapkan media gambar berseri adalah 78,4 yang di peroleh dari hasil bagi jumlah seluru nilai $\left(\sum \mathrm{X}\right)$ dengan jumlah siswa sampel $(\mathrm{N})$ atau $\left(\sum\right.$ $\mathrm{X} / \mathrm{N})=1,960 / 25=78,4$ ). Berdasarkan data tersebut maka siswa kelas VIII SMP Negeri 7 Palopo sudah mampu menulis cerpen dengan memanfaatkan media gambar berseri.
\end{abstract}

Kata kunci : Media gambar berseri, menulis cerpen.

\section{Pendahuluan}

Keterampilan menulis sebagai salah satu cara berkomunikasi dapat diartikan sebagai kemampuan seseorang dalam menyampaikan maksud kepada orang lain atau pembaca dengan menggunakan bahasa tulis yang baik dan benar sehingga apa yang ditulis dan disampaikan sesuai dengan apa yang diinginkan penulis. Keterampilan menulis pada prinsipnya yaitu melihat adanya hubungan antara keterampilan menulis dengan keterampilan membaca melalui penulis dan pembaca. Bila penulis menuliskan sesuatu, maka orang lain atau pembaca sedikit banyak akan telibat di dalamnya

Salah satu cara membuat kelas lebih hidup dan siswa lebih aktif, yakni dengan mendorong siswa berlatih untuk menulis kreatif. Ini dilakukan dengan memberikan tema-tema yang bersifat umum agar dapat dikembangkan sendiri oleh para siswa, berdasarkan pengamatan dan pengalaman mereka. Tema yang diberikan dapat diambil dari karya-karya sastra yang pernah dibaca oleh siswa, atau dapat diambil dari berbagai karya sastra yang pernah dikenalnya. Dalam kajian ini dipilih cerpen sebagai objek penelitian. Pemilihan cerpen dalam penelitian karena ada beberapa alasan. Pertama, menulis cerpen tidak memerlukan waktu yang lama disebabkan cerpen lebih pendek dibanding dengan novel. Kedua, bahasa yang digunakan dalam cerpen merupakan bahasa yang sederhana, lebih sederhana 
dibandingkan bahasa dalam puisi yang dengan bahasa yang singkat mampu merangkum semua ide cerita dalam satu rangkaian tema.

Pembelajaran bahasa dan sastra indonesia sesuai kurikulum pendidikan (2006) lebih diarahkan untuk meningkatkan kemampuan peserta didik untuk berkomunikasi dalam bahasa indonesia dengan baik dan benar, baik secara lisan maupun tulis serta menumbukan apresiasi terhadap hasil karya kesastraan indonesia (Depdiknas,2006:10).

Kemampuan siswa untuk berkomunikasi secara tertulis yang dimaksudkan adalah kemampuan menulis. kemampuan menulis adalah kemampuan untuk mengungkapkan pikiran, gagasan, ide, pendapat persetujuan, keinginan, menyampaikan suatu peristiwa dan lain lain.Pembelajaran menulis pada siswa SMP memberikan banyak manfaat, seperti mengembangkan kreativitas, menanamkan keberanian dan percaya diri, menata dan menjernikan pikiran, cara berpikir, kecerdasan dan kepekaan emosi, menuangkan ide atau gagasan pikiran pengalaman perasaan dan cara memandang kehidupan. Dengan banyak manfaat yang akan diperoleh dalam pembelajaran menulis selayaknya kegiatan menulis ini adalah salah satu kegiatan yang disukai siswa. Akan tetapi, Kenyataanya pebelajaran menulis menjadi kegitan yang sulit bagi siswa, sehingga mereka kurang berminat terhadap pembelajaran menulis.

Menulis pengalaman dalam sebuah cerpen biasanya ditulis berdasarkan rekaan atau imajinasi. Namun, narasi yang ditulis juga biasa berdasarkan pengalaman pribadi penulis. Cerpen sebagai salah satu prosa fiksi pada umumnya merupakan himpunan peristiwa yang disusun berdasarkan urutan waktu atau urutan kejadian.

\section{Kajian Teori}

Untuk lebih memperjelas penelitian ini, peneliti menjabarkan konsep dasar atau teori-teori yang relevan yang mendukung penelitian mengenai kemampuan menulis cerpen melalu penerapan media gambar siswa kelas VIII SMP Negeri 7 Palapo.

\section{Pengertian Menulis}

Menulis merupakan kegiatan penyampaian pesan dengan menggunakan tulisan sebagai mediumnya. Menulis adalah rangkaian proses berpikir. Proses berpikir berkaitan ereat dengan kegiatan penalaran. Penalaran yang baik dapat menghasilkan tulisan yang baik pula. Bahkan, tanpa penalaran tidak akan ada pengetahuan yang benar.

Syafi'ie (1998: 27) mengemukakan bahwa salah satu substansi retorika menulis adalah penalaran yang baik. Hal ini berarti untuk menghasilkan simpulan yang benar harus di lakukan penalaran secara cermat dengan berdasarkan pikiran yang logis. Penalaran yang salah akan menuntun kepada simpulan yang salah.

Kegiatan menulis itu ialah suatu proses, yaitu proses penlisan, yang melewati beberapa tahap, yakni pramenulis, penulisan, dan revisi. Ketiga tahap penulisan menunjukan kegiatan utama yang berbeda. Dalam tahap pramenulis akan ditentukan hal-hal pokok yang akan ditulis, sedangkan 
tahap penulisan akan dilakukan kegiatan mengembangkan gagasan dalam kalimat, paragraf, dan wacana (Akhadiah, dkk., 1994: 2).

Menulis merupakan suatu proses melahirkan suatu tulisan yang berisi gagasan. Banyak yang melakukannya secara spontan, tetapi juga ada yang berkali-kali mengadakan koreksi dan penulisan kembali (Sumardjo, 2001: 30). Senada dengan hal itu, California Project (dalam Deporter \& Hernacki, 2001: 50) menyatakan bahwa proses menulis itu meliputi (1) persiapan, mengelompokkan, dan menulis cepat, (2) draf kasar, gagasan dieksplorasi dan dikembangkan, (3) berbagi, seorang rekan membaca draf tersebut dan memberikan umpan balik, (4) memperbaiki, dan umpan balik, perbaiki tulisan tersebut dan bagikan lagi, (5) penyuntingan, perbaiki semua kesalahan, tata bahasa, dan tanda baca, (6) penulisan kembali, memasukan isi yang baru dan perubahan penyuntingan, dan (7) evaluasi, periksalah apakah tugas ini sudah selesai.

Pada waktu proses penulisan berlangsung setiap orang akan melewati tahapan menulis yang sama, yaitu pramenulis, pemburaman/pengendrafan, dan perevisian untuk memperbaiki tulisan yang sudah dihasilkan. Pada dasarnya, ada lima tahap proses kreatif menulis, yaitu: (1) persiapan, pada tahap ini penulis menyadari apa yang akan ditulis, (2) inkubasi, pada tahap ini gagasan yang telah muncul tadi direnungkan oleh penulis, (3) inspirasi, pada tahap ini penulis menyadari apa yang akan ditulis, (4) penulisan, pada tahap ini penulis mengungkapkan apa yang inngin ditulis, dan (5) revisi.

Uraian dan penjelasan tentang proses menulis yang telah dikemukakan diatas pada hakikatnya sama. Proses menulis merupakan kegiatan mengungkapkan ide atau gagasan, pikiran, perasaan, dan pengalaman melalui tahapan menulis. Seorang yang melakukan kegiatan menulis disadari atau tidak akan selalu melalui suatu tahapan dalam proses yang dilakukan. Tahapan dalam proses menulis tersebut secara umum meliputi kegiatan pramenulis, penulisan, dan revisi hasil tulisan. Tahap- tahap yang dilewati seorang penulis pada waktu menuangkan gagasannya akan menjadi panduan untuk menghasilkan suatu tulisan yang sesuai denngan apa yang direncanakn.

Menulis kreatif merupakan kegiatan menulis yang berkembang dan gagasan yang kreatif. Mirriam (2006 :169) menyarankan bahwa menulis kreatif merupakan gagasan yang mengalir dari pikiran seseorang kedalam sebuah tulisan. Gagasan kreatif yang sudah diungkapkan dalam bentuk tulisan akan menggambarkan hal-hal yang ingin dikembangkan oleh penulis.

\section{Media gambar berseri}

1) Pengertian media gambar berseri

Menurut Djamarah dan Zain (Abbas, Hasnindah, 2011:8), secara umum media data diklarifikasikan atas tiga jenis, yaitu: media auditif (mengandalkan kemampuan suara), media visual (mempunyai unsur gambar), dan media audio-visual (mempunyai unsure suara dan gambar). Media yang dimaksud dalam kajian ini adalah media gambar berseri dalam pembelajaran yang hanya mempunyai unsur gambar berupa gambar berseri sebagai media visual. 
Sapari (Abbas, Hasnindah, 2011:8) mengemukakan bahwa media gambar seri merupakan serangkaian gambar yang terdiri dari 2 hingga 6 gambar yang menceritakan satu kesatuan cerita yang dapat dijadikan alur pemikiran siswa dalam mengarang, setiap gambar dapat dijadikan paragraf.

Pendapat di atas menegaskan bahwa media gambar seri adalah media yang berseri, dimana setiap gambar memiliki kaitan antara satu dengan yang lainnya. Masing-masing gambar dalam media gambar seri mengandung makna adanya alur cerita yang seharusnya sehingga mengandung makna tertentu, dan gambar-gambar tersebut dapat dibuat dalam bentuk cerita atau karangan yang menarik.

2) Fungsi dan manfaat media gambar berseri sebagai media visual

Keberadaan media pembelajaran seperti media gambar berseri memiliki fungsi dan manfaat tertentu sehingga dapat mendukung proses pembelajaran yang berkualitas. Fungsi dan manfaat media pembelajaran akan sangat terkait dengan bentuk dan jenis media pembelajaran yang digunakan, seperti media gambar yang sifatnya berseri atau terdiri dari beberapa gambar yang memiliki keterkaitan antara gambar yang satu dengan yang lainnya.

Media gambar seri merupakan jenis media visual atau hanya mempunyai unsur gambar. Fungsi media visual dalam pembelajaran menurut Levie \& Lentz (Arsyad, 2011:16), yaitu fungsi atensi, fungsi afekif, fungsi kognitif dan fungsi kompensatoris. Keempat fungsi media visual tersebut akan diuraikan sebagai berikut:

a) Fungsi atensi dari media visual, seperti media gambar seri yang dapat menarik dan mengarahkan perhatian siswa untuk berkonsentrasi terhadap isi pelajaran yang ditampilkan atau menyertai teks materi pelajaran. Contohnya, ketika siswa bosan mendengarkan ceramah guru, maka guru memperlihatkan gambar-gambar yang berkaitan dengan materi pelajaran. Ini dapat menarik perhatian dan konsentrasi siswa terhadap materi pelajaran karena adanya media yang dapat dilihat langsung.

b) Fungsi afektif dari media visual, seperti media gambar seri yang digunakan guru akan menggugah emosi dan sikap siswa misalnya informasi yang menyankut masalah sosial atau ras dalam kehidupan sehari-hari. Penggunaan gambar berseri diupayakan menggugah perasaan siswa tentang berbagai peristiwa melalui gambar-gambar yang disajikan secara berseri.

c) Fungsi kognitif dari media visual, seperti gambar seri akan dapat memperlancar pencapaian tujuan untuk memahami dan mengingat informasi atau pesan yang terkandung dalam gambar. Jadi, penggunaan media gambar seri sebagai media visual akan meningkatkan daya pikir siswa terhadap materi pelajaran.

d) Fungsi kompensatoris dari media visual, seperti media gambar seri akan memberikan konteks untuk memahami teks dan membantu siswa yang lemah dalam membaca untuk mengorganisasikan informasi dalam teks dan dapat mengingat kembali. Hal ini sangat penting dalam menerima dan memahami isi pelajaran yang disajikan dengan teks atau disajikan 
secara verbal, karena murid dapat melihat secara langsung mengaitkan dengan materi pelajaran.

Berdasarkan pendapat di atas, jelas bahwa media memiliki fungsi yang sangat luas dan penting, terlebih dalam dunia pendidikan, sebagaimana digunakan guru dalam proses pembelajaran. walaupun dalam pengadaan dan pemanfaatan senantiasa masih menghadapi berbagai kendala, baik karena tidak disiapkan oleh pihak sekolah maupun keterbatasan kemampuan guru dalam membuat dan menggunakan media pembelajaran seperti gambar seri.

\section{Metode Penelitian \\ Jenis Penelitian}

Penelitian ini termasuk penelitian eksperimen yang berusaha membuktikan apakah dengan menggunakan media gambar berseri cocok dipahami dalam pembelajaran mengapresiasi menulis cerpen siswa kelas VIII atau tidak.

\section{Lokasi dan Waktu penelitian}

\section{Lokasi}

Lokasi penelitian ini dilaksanakan di SMP Negeri 7 Palopo pada semester ganjil.

\section{Waktu}

Waktu penelitian ini berlangsung pada bulan juni sampai Agustus 2017.

\section{Populasi dan Sampel}

\section{Populasi}

Populasi dalam penelitian adalah sumber informasi dan sumber data yang akan diselidiki. Penelitian ini disajikan adalah siswa kelas VIII SMP Negeri 7 Palopo tahun pelajaran 2017-2018 yang berjumlah 25 siwa Tabel. 1 Populasi Penelitian

\begin{tabular}{ccc}
\hline No & Kelas & Jumlah Siswa \\
\hline 1 & VIII A & 25 \\
2 & VIII B & 25 \\
3 & VIII C & 27 \\
4 & VIII D & 28 \\
5 & VIII E & 27 \\
6 & VIII F & 31 \\
\hline Jumlah & & 163
\end{tabular}

Sumber: tata usaha SMP Negeri 7 Palopo

\section{Sampel}

Sampel dari sebagian atau wakil dari populasi yang dapat di teliti.pengambilan sampel dalam penelitian ini dilakukan dengan menentukan langsung dengan pertimbangan bahwa semua kelas memiliki pertimbangan bahwa semua kelas memiliki kesempatan yang sama dan cukup homogen,artinya tidak ada satu kelas dengan kelas yang lainya untuk dijadikan sampel pengambilan sampel semacam ini dikenal dengan sampel bertujuan.

Adapun sampel yang dapat diterapkan secara random sampling mengambil secara acak berdasarkan tingkatnya. Untuk lebih jelasnya smapel dapat dilihat pada tabel berikut. 
Tabel 2. Keadaan Populasi

\begin{tabular}{|c|c|c|c|c|}
\hline \multirow[b]{2}{*}{ No } & \multirow{2}{*}{ Kelas } & \multicolumn{2}{|c|}{ Jenis kelamin } & \multirow{2}{*}{ Jumlah } \\
\hline & & Laki-laki & Perempuan & \\
\hline 1 & VIII & 8 & 17 & 25 \\
\hline Jumlah & & 8 & 17 & 25 \\
\hline
\end{tabular}

Sumber: Tata Usaha SMPN 7 Palopo.

\section{Teknik Pengumpulan Data}

Data diperoleh melalui kelas prettest dan posttest adalah langkah langkah sebagai berikut :

1. Langkah pertama adalah memberikan test awal.

2. Langkah kedua adalah memberikan treatment (perlakuan).

3. Langkah yang ketiga adalah memberikan tes .

Tes yang digunakan untuk mengukur kemampuan siswa dalam aspek kognitif atau penguasaan materi pembelajaran setelah diberikan penjelasan materi pelajaran oleh guru adalah tes uraian bebas. Instrumen tes yang digunakan dalam penelitian ini berupa tes kemampuan dengan format tes uraian bebas. Tes ini dilakukan untuk mengetahui dan mengukur nilai ratarata siswa dalam menulis karangan narasi sebelum dan sesudah penerapan media gambar berseri.

\section{Teknik Analisis Data}

Data yang diperoleh dari penelitian ini dianalisis dengan menggunakan teknik analisis presentasi dan deskriptif. Teknik ini digunakan untuk memperoleh data yang diperoleh dari hasil test kemampuan menulis cerpen melalui penerapan media gambar berseri siswa kelas VIII SMP Negeri 7 Palopo.

Hasil penelitian berupa data yang masih mentah yang diperoleh, akan diolah dengan menggunakan teknik deskriptif. Adapun langkah-langkah menganalisis data adalah:

1. Membuat daftar skor mentah peserta sampel. Setelah pelaksanaan test, kegiatan berikutnya adalah mengoreksi pekerjaan siswa. Pekerjaan mengoreksi adalah menentukan dan menghitung jumlah jawaban betul siswa terhadap butir-butir test yang dikerjakannya. Skor yang diperoleh dengan cara diatas adalah skor mentah.

2. Membuat distribusi frekuensi dari skor mentah. Data test yang diperoleh dari kerja koreksi pada umumnya masih dalam keadaan tak menentu. Untuk memudahkan analisis selanjutnya, yaitu dengan membuat tabulasi kemudian menghitung frekuensi setiap skor. Jika memilih cara tersebut berarti peneliti akan menyusun distribusi frekuensi yang dapat memudahkan penghitungan selanjutnya.

3. Mencari rata-rata

$$
\mathrm{Xi}=60 \% \mathrm{x} \text { skor maksimal }
$$

4. Membuat standar deviasi

$$
\mathrm{Si}=\mathrm{I} / 4 \times \mathrm{Xi}
$$

Halaman | 285 
5. Membuat skala nilai $10-100$

6. Tabel 3. Konversi angka hasil belajar kedalam nilai berskala 10-100

\begin{tabular}{|c|c|c|c|}
\hline Skala sigma & Nilai & Skala angka & $\begin{array}{c}\text { Ekuivalensi nilai } \\
\text { mentah }\end{array}$ \\
\hline$+2,25$ & 100 & Mean $+(2,25$ X DS $)$ & ........................... \\
\hline$+1,75$ & 90 & Mean + $(1,75$ X DS $)$ & ............................ \\
\hline$+1,25$ & 80 & Mean $+(1,25 \times$ DS $)$ & 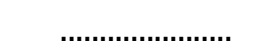 \\
\hline$+0,75$ & 70 & Mean + $(0,75$ X DS $)$ & …………........... \\
\hline$+0,25$ & 60 & Mean $+(0,25$ X DS $)$ & ......................... \\
\hline$-0,25$ & 50 & Mean - $(0,25$ X DS $)$ & ......................... \\
\hline$-0,75$ & 40 & Mean - $(0,25$ X DS $)$ & .......................... \\
\hline$-1,25$ & 30 & Mean - $(1,25$ X DS $)$ & 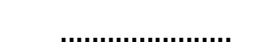 \\
\hline$-1,75$ & 20 & Mean - (1,75 X DS $)$ & ......................... \\
\hline$-2,25$ & 10 & Mean - $(2,25$ X DS $)$ & .......................... \\
\hline
\end{tabular}

Sumber: Nurgiyantoro, 2001:39

7. Membuat tolok ukur kemampuan siswa

8. Menentukan frekuensi kuantitatif perolehan nilai.

Data yang diperoleh dari tabel frekuensi dan presentase kemudian disimpulkan seperti pada tabel berikut:

Tabel 4. Frekuensi kuantitatif perolehan nilai

\begin{tabular}{|c|c|c|c|}
\hline No & Perolehan nilai & Frekuensi & Presentasi \\
\hline 1 & Nilai $\geq 75$ ke atas & . & ……......... \\
\hline 2 & Nilai $\leq 75$ dibawah & ................... & ................ \\
\hline
\end{tabular}

Sumber: Standar ketuntasan minimal SMPN 7 Palopo

Sampel dikatakan tuntas apabila memperoleh nilai 70 keatas, dan dianggap tidak tuntas jika sampel memperoleh nilai dibawah 70 .

Tabel 5. Pedoman penilaian menulis

\begin{tabular}{clc}
\hline No & Aspek yang dinilai & Skor maksimal \\
\hline 1 & Kesesuaian dengan tema & 30 \\
2 & Organisasi & 20 \\
3 & Diksi & 10 \\
4 & Toko penokohan & 20 \\
5 & Ejaan & 10 \\
\hline
\end{tabular}

Sumber : Nurgiyantoro (2012: 441)

9. Memberikan interprestasi terhadap prestasi siswa dengan skor sebagai berikut:

Tabel 6. Interprestasi terhadap prestasi siswa

\begin{tabular}{ccc}
\hline No & Interval & Skor \\
\hline 1 & $90-100$ & Sangat tinggi \\
2 & $80-89$ & Tinggi \\
3 & $65-79$ & Sedang \\
4 & $55-64$ & Rendah \\
5 & $0-54$ & Sangat rendah \\
\hline
\end{tabular}


Sumber: Nurgiyantoro, 2001:44

\section{Hasil Penelitian}

Hasil penelitian pada bab ini dapat dideskripsikan secara rinci berdasarkan data yang diperoleh di lapangan. Hasil kuantitatif yang dimaksud adalah hasil yang dinyatakan dalam bentuk angka untuk mengetahui mampu tidaknya media gambar berseri dalam meningkatkan kemampuan menulis cerpen pada siswa kelas VIII SMP Negeri 7 Palopo. Data yang diperoleh di lapangan selanjutnya dianalisis sesuai dengan teknik analisis data yang telah dikemukakan pada bab III, yaitu menggunakan analisis statistik eksperimen. Penyajian analisis terdiri atas dua kategori yaitu penyajian data nilai belajar pretest dan hasil analisis data posttest. Penyajian dapat dilihat seperti berikut ini.

1. Analisis data statistik deskriptif hasil pembelajaran menulis cerpen dengan menggunakan media gambar berseri pada siswa kelas VIII SMP Negeri 7 Palopo (pretest)

Pelaksanaan menulis cerpen pada pretest kelas VIII SMP Negeri 7 Palopo dengan 25 siswa dapat diperoleh gambaran, yaitu 2 siswa yang mampu memperoleh nilai 85 sebagai skor maksimal. Skor yang diperoleh siswa di tes awal (pretest) yaitu skor 85 yang diperoleh oleh 2 siswa. Skor 80 diperoleh 3 siswa, skor 75 diperoleh 4 siswa, skor 70 diperoleh 3 siswa, skor 65 diperoleh 5 siswa, skor 60 diperoleh 5 siswa, skor 55 diperoleh 3 siswa.

Gambaran yang lebih jelas dari skor yang tertinggi sampai skor terendah yang diperoleh siswa beserta frekuensinya pada pretest dapat dilihat pada tabel berikut ini

Tabel 7. Distribusi frekuensi dan persentase skor hasil pembelajaran siswa pada pretest siswa kelas VIII SMP Negeri 7 Palopo

\begin{tabular}{cccc}
\hline No & Nilai & Frekuensi & Persentase\% \\
\hline 1 & 85 & 2 & 8 \\
2 & 80 & 3 & 12 \\
3 & 75 & 4 & 16 \\
4 & 70 & 3 & 12 \\
5 & 65 & 5 & 20 \\
6 & 60 & 5 & 20 \\
7 & 55 & 3 & 12 \\
\hline umlah & & 25 & 100 \\
\hline
\end{tabular}

Sumber: Data primer setelah diolah (2017)

Setelah ditranformasikan ke dalam nilai berskala 10-100 terlebih dahulu ditentukan mean ideal dengan rumus :

$$
\begin{aligned}
& X i=60 \% \text { X Skor maksimal } \\
& X i=60 \% \text { X } 100 \\
& X i=60
\end{aligned}
$$

Langkah selanjutnya adalah mencari standar deviasi sebagai ukuran penyebaran data dengan rumus yang digunakan untuk menentukan standar deviasi data tersebut:

$$
\begin{aligned}
\mathrm{Si} & =1 / 4 \times \mathrm{Xi} \\
& =1 / 4 \times 60 \\
& =15
\end{aligned}
$$


Berdasarkan hal di atas, standar deviasi data tersebut adalah 15. Selanjutnya mean dan standar deviasi yang diperole ditransfer kedalam konversi angka berskala 10-100. Untuk lebih jelasnya dapat dilihat pada tabel berikut

Tabel 8. Konversi angka hasil kemampuan siswa menulis cerpen pretest di kelas VIII SMP Negeri 7 Palopo ke dalam nilai berskala 10-100

\begin{tabular}{cccc}
\hline Skala Sigma & Nilai & Skala Angka & kuivalensi Nilai Mentah \\
\hline$+2,25$ & 100 & $60+(2,25 \times 15)=93,75$ & $94-100$ \\
$+1,75$ & 90 & $60+(1,75 \times 15)=86,25$ & $86-93$ \\
$+1,25$ & 80 & $60+(1,25 \times 15)=78,75$ & $79-85$ \\
$+0,75$ & 70 & $60+(0,75 \times 15)=71,25$ & $71-78$ \\
$+0,25$ & 60 & $60+(0,25 \times 15)=63,75$ & $64-70$ \\
$-0,25$ & 50 & $60-(0,25 \times 15)=56,25$ & $56-63$ \\
$-0,75$ & 40 & $60-(0,75 \times 15)=48,75$ & $49-55$ \\
$-1,25$ & 30 & $60-(1,25 \times 15)=41,25$ & $41-48$ \\
$-1,75$ & 20 & $60-(1,75 \times 15)=33,75$ & $34-40$ \\
$-2,25$ & 10 & $60-(2,25 \times 15)=32,25$ & $\leq 33$ \\
\hline
\end{tabular}

Sumber: Data primer setelah diolah(2017)

Berdasarkan Tabel 8 skor mentah siswa dapat dikonversi ke dalam nilai 10-100 dan dapat pula diketahui frekuensi dan presentase nilai siswa. Perolehan nilai seluruh siswa beserta frekuensinya dapat di lihat secara jelas pada tabel 9 berikut ini.

Tabel 9. Jumlah nilai pretest kelas VIII SMP Negeri 7 Palopo

\begin{tabular}{lcccc}
\hline No & Nilai siswa $(\mathrm{X})$ & Frekuensi $(\mathrm{N})$ & Jumlah nilai $\left(\sum \mathrm{X} . \mathrm{a}\right)$ & Rata-rata \\
\hline 1 & 85 & 2 & 170 & \\
\hline 2 & 80 & 3 & 240 & \\
\hline 3 & 70 & 7 & 490 & 66,6 \\
\hline 4 & 60 & 10 & 600 & \\
\hline 5 & 55 & 3 & 165 & \\
\hline Jumlah & & 25 & 1,665 &
\end{tabular}

Sumber : Data primer setelah diolah (2017)

Berdasarkan Tabel 11, diketahui bahwa nilai rata-rata siswa kelas VIII SMP Negeri 7 Palopo pada saat pretest adalah 70 yang diperoleh dari hasil bagi jumlah seluruh nilai $(\Sigma \mathrm{X})$ dengan jumlah siswa sampel $(\mathrm{N})$ atau $(\Sigma \mathrm{X} / \mathrm{N}=$ $1,665 / 25=66,6)$.

Hasil rata-rata siswa tersebut dapat di konversi ke dalam tabel 10 klasifikasi tingkat hasil belajar siswa. Untuk mengetahui tingkat hasil belajar menulis cerpen melalui kelas VIII SMP Negeri 7 Palopo pada saat pretest dapat dilihat pada tabel 10 berikut

Tabel 10. Klasifikasi hasil pretest kelas VIII SMP Negeri 7 Palopo

\begin{tabular}{cccc}
\hline Kategori & Skor & Frekuensi & Persentase(\%) \\
\hline Sangat Tinggi & $90-100$ & - & - \\
Tinggi & $80-89$ & 5 & 20 \\
Sedang & $65-79$ & 7 & 28 \\
Rendah & $55-64$ & 10 & 40 \\
Sangat Rendah & $0-54$ & 3 & 12 \\
\hline Jumlah & & 25 & 100 \\
\hline
\end{tabular}


Sumber : Data primer setelah diolah (2017)

Tabel 11, menunjukan bahwa tidak ada siswa yang berada pada kategori sangat tinggi, kategori tinggi diperoleh 5 siswa (20\%), kategori sedang diperoleh 7 siswa (28\%), kategori rendah diperoleh 10 siswa (40\%), dan kategori sangat rendah diperoleh 3 siswa (12\%). Setelah diperoleh nilai hasil kemampuan menulis cerpen dapat disimpulkan bahwa kemampuan siswa termasuk dalam kategori rendah.

Tabel 11. Hasil pencapaian KKM pretest kelas eksperimen terhadap keterampilan menulis cerpen

\begin{tabular}{cccc}
\hline No & Perolehan nilai & Frekuensi & Persentasi \% \\
\hline 1 & Nilai $\geq 75$ ke atas & 12 & 48 \\
2 & Nilai $\leq 75$ dibawah & 13 & 52 \\
\hline Jumlah & & 25 & 100 \\
\hline
\end{tabular}

Sumber: data primer setelah diolah (2017)

Berdasarkan tabel tersebut di atas dapat diketahui bahwa hasil pencapaian KKM kemampuan menulis cerpen siswa kelas VIII SMP Negeri 7 Palopo, yang mendapat nilai 75 ke atas sebanyak 12 siswa (48\%), sedangkan yang mendapatkan nilai 75 ke bawah sebanyak 13 siswa (52\%). Dengan demikian, dapat dikatakan sudah memadai apabila dikonfirmasikan dengan nilai KKM sekolah pada mata pelajaran bahasa Indonesia yaitu siswa dinyatakan mampu apabila mencapai 75\% siswa yang memperoleh nilai 75 ke atas.

\section{Analisis data statistik deskriptif hasil pembelajaran menulis cerpen dengan menggunakan media gambar berseri pada siswa kelas VIII SMP Negeri 7 Palopo (posttest)}

Pelaksanaan pembelajaran menulis cerpen pada tahap ini dengan menerapkan media gambar berseri pada pembelajaran menulis cerpen yang diterapkan dalam KTSP (Kurikulum Tingkat Satuan Pendidikan). Guru menjelaskan pengertian karangan cerpen, ciri-ciri cerpen, unsur-unsur cerpen, jenis-jenis cerpen, teknik penulisan cerpen, proses dan tahap penulisa cerpen, cerpen yang baik, dan tujuan menulis cerpen, guru menjelaskan tentang media gambar berseri, kemudian siswa diarahkan menulis cerpen berdasarkan gambar berseri yang telah dibagikan. Posttest dilakukan setelah siswa diberikan perlakuan barupa penerapan media gambar berseri pada pembelajaran menulis cerpen. Hal ini dilakukan untuk mengetahui kemampuan siswa dalam menulis cerpen melalui media gambar berseri.

Berdasarkan hasil analisis data posttest kelas VIII SMP Negeri 7 dari 25 siswa diperoleh hasil 5 siswa yang mampu memperoleh nilai 95, sebagai nilai maksimal. Nilai 95 diperoleh 5 siswa, nilai 90 diperoleh 4 siswa, nilai 85 diperoleh 4 siswa, nilai 80 diperoleh 3 siswa, nilai 75 diperoleh 3 siswa, nilai 70 diperoleh 3 siswa, nilai 65 diperoleh 2 siswa, dan nilai 60 diperoleh 1 siswa. 
Gambaran yang lebih jelas dari skor yang tertinggi sampai skor terendah yang diperoleh siswa beserta frekuensinya pada posttest dapat dilihat pada tabel berikut ini.

Tabel 12. Distribusi frekuensi dan persentase skor hasil pembelajaran siswa pada posttest siswa kelas VII SMP Negeri 7 Palopo

\begin{tabular}{cccc}
\hline No & Nilai & Frekuensi & Persentase\% \\
\hline 1 & 95 & 5 & 20 \\
2 & 90 & 4 & 16 \\
3 & 85 & 4 & 16 \\
4 & 80 & 3 & 12 \\
5 & 75 & 3 & 12 \\
6 & 70 & 2 & 8 \\
7 & 65 & 2 & 8 \\
8 & 60 & 2 & 8 \\
\hline umlah & & 25 & 100
\end{tabular}

Sumber: Data primer setelah diolah (2017)

Skor mentah ditransformasikan ke dalam nilai berskala 10-100 terlebih dahulu ditentukan mean ideal dengan rumus :

$\mathrm{Xi}=60 \% \mathrm{X}$ Skor maksimal

$\mathrm{Xi}=60 \% \mathrm{X} 100$

$\mathrm{Xi}=60$

Langkah selanjutnya adalah mencari standar devisiasi sebagai ukuran penyebaran data. Rumus yang digunakan untuk menentukan standar devisiasi data tersebut :

$$
\begin{aligned}
\mathrm{Si} & =1 / 4 \times \mathrm{Xi} \\
& =1 / 4 \times 60 \\
& =15
\end{aligned}
$$

Berdasarkan hal di atas, standar devisiasi data tersebut adalah 15. Selanjutnya, mean dan standar devisiasi yang telah diperoleh ditransfer kedalam konversi angka berskala 10-100. Untuk lebih jelasnya perhatikan tabel 13 berikut ini:

Tabel 13. Konversi angka hasil kemampuan siswa menulis cerpen posttest di kelas

VIII SMP Negeri 7 Palopo ke dalam nilai berskala 10-100

\begin{tabular}{cccc}
\hline Skala Sigma & Nilai & Skala Angka & $\begin{array}{c}\text { kuivalensi Nilai } \\
\text { Mentah }\end{array}$ \\
\hline$+2,25$ & 100 & $60+(2,25 \times 15)=93,75$ & $94-100$ \\
$+1,75$ & 90 & $60+(1,75 \times 15)=86,25$ & $86-93$ \\
$+1,25$ & 80 & $60+(1,25 \times 15)=78,75$ & $79-85$ \\
$+0,75$ & 70 & $60+(0,75 \times 15)=71,25$ & $71-78$ \\
$+0,25$ & 60 & $60+(0,25 \times 15)=63,75$ & $64-70$ \\
$-0,25$ & 50 & $60-(0,25 \times 15)=56,25$ & $56-63$ \\
$-0,75$ & 40 & $60-(0,75 \times 15)=48,75$ & $49-55$ \\
$-1,25$ & 30 & $60-(1,25 \times 15)=41,25$ & $41-48$ \\
$-1,75$ & 20 & $60-(1,75 \times 15)=33,75$ & $34-40$ \\
$-2,25$ & 10 & $60-(2,25 \times 15)=32,25)$ & $\leq 33$ \\
\hline
\end{tabular}

Sumber: Data yang telah diolah (2017) 
Berdasarkan tabel 13 skor mentah siswa dapat dikonversi ke dalam nilai 10-100 dan dapat pula diketahui frekuensi dan persentase nilai siswa. Perolehan nilai seluruh siswa beserta frekuensinya dapat dilihat secara jelas pada tabel 14 berikut ini

Tabel 14. Jumlah nilai posttest klas VIII SMP Negeri 7 Palopo ( $\Sigma X . a)$

\begin{tabular}{ccccc}
\hline No & Nilai siswa $(\mathrm{X})$ & Frekuensi $(\mathrm{N})$ & imlah nilai $\left(\sum \mathrm{X} . \mathrm{a}\right)$ & Rata-rata \\
\hline 1 & 90 & 9 & 810 & 78,4 \\
2 & 80 & 7 & 560 & \\
3 & 70 & 5 & 350 & \\
4 & 60 & 4 & 240 & \\
\hline Jumlah & \multicolumn{5}{l}{} \\
\hline
\end{tabular}

Sumber: Data primer setelah diolah (2017)

Berdasarkan Tabel 14 diketahui bahwa nilai rata-rata siswa kelas VIII SMP Negeri 7 Palopo pada saat posttest (X) adalah 77,57 yang diperoleh dari hasil bagi jumlah seluruh nilai $(\Sigma \mathrm{X})$ dengan jumlah siswa sampel $(\mathrm{N})$ atau $(\Sigma$ $\mathrm{X} / \mathrm{N})=1,960 / 25=78,4$ ).

Hasil rata-rata siswa tersebut dapat dikonversi kedalam tabel 15 klasifikasi tingkat hasil belajar siswa. Untuk mengetahui tingkat hasil belajar menulis cerpen pada saat posttest dapat dilihat pada tabel 15 berikut ini.

Tabel 15. Klasifikasi tingkat hasil belajar menulis cerpen kelas VIII SMP

Negeri 7 Palopo

\begin{tabular}{cccc}
\hline Kategori & Skor & Frekuensi & Presentasi (\%) \\
\hline Sangat Tinggi & $90-100$ & 9 & 36 \\
Tinggi & $80-89$ & 7 & 28 \\
Sedang & $65-79$ & 7 & 28 \\
Rendah & $55-64$ & - & - \\
Sangat Rendah & $0-54$ & - & - \\
\hline Jumlah & & 25 & 100 \\
\hline
\end{tabular}

Sumber: Data primer setelah diolah (2017)

Berdasarkan tabel 15, di atas diketahui bahwa nilai posttest berada pada kategori sangat tinggi diperoleh 9 siswa (36\%), kategori tinggi diperoleh 7 siswa (28\%), kategori sedang diperoleh 7 siswa (28\%), tidak ada siswa yang berada pada kategori rendah dan tidak ada siswa yang berada pada kategori sangat rendah. Setelah diperoleh nilai hasil kemampuan menulis cerpen dapat disimpulkan bahwa kemampuan siswa kelas VIII SMP Negeri 7 Palopo setelah diberi perlakuan termasuk dalam kategori sangat tinggi.

Tabel 16. Hasil pencapaian KKM posttest kelas VIII SMP Negeri 7 Palopo terhadap keterampilan menulis cerpen berdasarkan gambar berseri

\begin{tabular}{cccc}
\hline No & Perolehan nilai & Frekuensi & Persentasi \% \\
\hline 1 & Nilai $\geq 75$ keatas & 21 & 84 \\
2 & Nilai $\leq 75$ dibawah & 4 & 16 \\
\hline Jumlah & & 25 & 100 \\
\hline
\end{tabular}

Sumber: data primer setelah diolah (2017) 
Berdasarkan tabel tersebut di atas dapat diketahui bahwa hasil pencapaian KKM kemampuan menulis cerpen siswa kelas VIII SMP Negeri 7 Palopo, yang mendapat nilai 75 ke atas sebanyak 19 siswa (84\%), sedangkan yang mendapatkan nilai 75 ke bawah sebanyak 6 siswa (16\%). Dengan demikian, dapat dikatakan sudah memadai apabila dikonfirmasikan dengan nilai KKM sekolah pada mata pelajaran bahasa Indonesia yaitu siswa dinyatakan mampu apabila mencapai $75 \%$ siswa yang memperoleh nilai 75 keatas.

\section{Pembahasan}

Pembelajaran adalah suatu proses yang dilaksanakan secara sistematik pada setiap komponen yang saling berpengaruh. Secara proses implisit terdapat kegiatan memilih, menciptakan, dan mengembangkan teknik untuk mencapai hasil pembelajaran yang diinginkan.

Pembahasan hasil penelitian didasarkan pada data temuan penelitian pada pretest dan posttest melalui pembelajaran menulis cerpen siswa kelas VIII SMP Negeri 7 Palopo. Agar terarah pada penelitian, langkah yang dilakukan yaitu melihat kondisi pembelajaran pada pretest dan posttest. Pengaruh media gambar berseri dalam kegiatan menulis cerpen dapat dilihat pada pemerolehan nilai rata-rata siswa tes awal dari 25 siswa, nilai rata-rata yang diperoleh siswa adalah 65,6 nilai tertinggi 85 nilai terendah 55 dan range 30 sedangkan posttest atau setelah diberi tindakan atau perlakuan nilai rata-rata yang diperoleh siswa adalah 78,4 nilai tertinggi 95 diperoleh 5 siswa, nilai terendah 60, diperoleh 2 Siswa.

Hal tersebut menunjukan adanya peningkatan dari hasil pretest ke posttest. Perbedaan yang signifikan antara yang menerapkan media gambar dengan menerapkan model konvensional dengan melihat nilai rata-rata yang diperoleh dari hasil pretest mencapai 65,6 sedangkan nilai rata-rata posttest mecapai 78,4.

Dengan demikian, data dikatakan bahwa tingkat pembelajaran menulis cerpen siswa kelas VIII SMP Negeri 7 Palopo sudah memadai karena apabila dikonfirmasikan dengan nilai KKM sekolah pada mata pelajaran bahasa Indonesia, yaitu siswa dinyatakan mampu apabila jumlah siswa mencapai $75 \%$ yang memperoleh nilai 75 ke atas. 


\section{Simpulan}

Bedasarkan hasil penelitian dan pembahasan yang telah diuraikan pada bab sebelumnya, maka dapat diambil simpulan sebagai berikut: hasil dari pemebelajaran media gambar berseri terhadap kemampuan dalam menulis cerpen di kelas VIII SMP Negeri 7 Palopo memiliki hasil yang kurang dilihat dari skor rata-rata yang diperoleh siswa yaitu skor rata-rata pretest 48\% berada pada interval 60-79 dikategorikan sedang dan skor rata-rata posttest $84 \%$ berada pada interval 90-100 dikategorikan sangat tinggi apabila dikonfirmasikan dengan nilai KKM sekolah pada mata pelajaran bahasa Indonesia, yaitu siswa dinyatakan mampu apabila jumlah siswa mencapai $75 \%$ yang memperoleh nilai 75 ke atas.

\section{Daftar Pustaka}

Abbas, Hasnindah. 2011. Meningkatkan Hasil Belajar Bahasa Indonesia Keterampilan Menulis Materi Membuat Karangan Melalui Media Gambar Seri pada Murid Kelas V SDN Sudirman III Makassar. Skripsi. Tidak diterbitkan. FIP UNM. Makassar.

Ahmadi, Muksin. 1990. Strategi Belajar Mengajar Keterampilan Berbahasa dan Apresiasi Sastra. Usaha Nasional. Malang.

Akhadiah, Sabarti dkk. 1995. Menulis.Depdiknas. Jakarta.

Aminuddin. 1990. Pengantar Apresiasi Karya Sastra. Sinar Baru. Bandung

Arikunto, Suharsimi. 2006. Prosedur Penelitian, Suatu Pendekatan Praktik. Depdiknas. Jakarta

Arsyad. 2011. Media Pembelajaran. PT. Raja Grafindo Persada. Jakarta

Azhar. 2000. Pengertian Media Pembelajaran. Sinar Baru Aglesindo. Bandung Depdiknas. 2006. Kurikulum Tingkat Satuan Pendidikan. Depdiknas. Jakarta

De Porter, Bobby dan Hernacki. 2007. Quantum Learning: Membiasakan Belajar nyaman dan Menyenangkan. KAIFA. New York.

Gani, Razinur. 1998. Pengajaran Sastra Indonesia Respond dan Analisis.: Depdikbud. Jakarta

Hasnindar. 2016. Keefektifan Media Gambar Berseri dalam Pembelajaran Menulis Cerpen Siswa Kelas VII SMPN 7 Palopo. Skripsi. Tidak diterbitkan. Pendidikan Bahasa dan Sastra Indonesia. Universitas Cokroaminoto Palopo.

Herlina, B. 2012. Keefektifan Strategi Belajar Show Not Tell dalam Pembelajaran Menulis Cerpen Siswa Kelas X SMA Negeri 1 Kaluku Kabupaten Mamuju. Skripsi. Tidak diterbitkan. Pendidikan Bahasa dan Sastra Indonesia. Universitas Cokroaminoto Palopo.

Keraf, Goris. 2000. Diksi dan Gaya Bahasa. Gramedia Pustaka Media: Jakarta Lubis, Mochtar. 1960. Teknik Mengarang. Balai Pustaka. Jakarta

Miriam, Caryn. 2006. Daripada Bete, Nulis Aja. Kaifa. Bandung

Nurgiyantoro. 2005. Penilaian Pengajaran Bahasa dan Sastra. BPFE. Yogyakarta

Sadiman. 1986. Tiga Belas Macam Media Pembelajaran. Raja Grafida Persada Jakarta. 
Sugiyono. 2014. Metode Penelitian Pendidikan (Pendekatan Kuantitatif, Kualitatif dan R\&D). Alfabeta .Bandung.

Sumardjo, J. 2001. Catatan Kecil tentang Menulis Cerpen. Pustaka Pelajar. Yogyakarta

Syafi'ie, Imam. Retorika dalam Menulis. Depdikbud. Jakarta

Tarigan, Henri Guntur. 2008. Menulis sebagai Suatu Keterampilan Berbahasa. Angkasa. Bandung

Wiyanto, Asul. 2004. Terampil Menulis Paragraf. Jakarta. Gramedia 